\title{
Image and Metaphor in the Philosophy of Wittgenstein
}

Kristóf Nyíri, Budapest

\section{Image-Blindness: A Prologue to Wittgenstein Scholarship}

Five or so decades after the publication of the Philosophical Investigations, the passage most often cited when it comes to characterizing the later Wittgenstein's view of images in thought and communication is still $\S 115$, regularly quoted together with $\S 116$, making up the lines:

A picture held us captive. And we could not get outside it, for it lay in our language and language seemed to repeat it to us inexorably.-When philosophers use a word-"knowledge", "being", "object", "I", "proposition", "name"and try to grasp the essence of the thing, one must always ask oneself: is the word ever actually used in this way in the language-game which is its original home? - What we do is to bring words back from their metaphysical to their everyday use. ${ }^{1}$

The 2004 volume Wittgenstein's Lasting Significance ${ }^{2}$ is as good an example as any. It has much to say about the early picture theory of language, but practically nothing about the later Wittgenstein's philosophy of pictures, while recurrently using the phrase 'being in the grip of a picture'. To talk about pictures, it appears here, is to talk about words. Or take Anja Weiberg's paper from the same year, "Ein Bild hielt uns gefangen": Die Kraft der Metapher"3, where the author understands 'picture' to mean, almost invariably, figure of speech. Her one notable exception is a brief reference to the phenomenon of seeing-as, a phenomenon Weiberg however immediately interprets as being grounded in linguistic, rather than in extra-linguistic, experience. ${ }^{4}$ 
Now it is of course indeed the case that what Wittgenstein, in $\S 115$, had in mind, is not a visual image, and everyday language clearly permits, for good reasons, the use of the word 'picture' in the sense of 'view', 'idea', 'notion'. What Wittgenstein here is saying is that our major handed-down philosophical notions were originally suggested, and are again and again reinforced, by certain figures of speech. But it is not at all the case that the later Wittgenstein invariably referred to linguistic formulas when he spoke of pictures. On the contrary, he had developed, as I will attempt to indicate, a variety of interesting ideas on how pictures function and visual images convey meaning, and how the verbal and the pictorial differ, and hang together - even if he did not succeed in synthesizing those ideas into a unified whole. Nor did he succeed in describing the kind of everyday usage alluded to in $\S 116$, the usage he thought constituted the original paradigm metaphysical language ought to be led back to. 'There is no trouble at all', Wittgenstein said in 1935,

with primitive languages about concrete objects. ... A substantive in language is used primarily for a physical body, and a verb for the movement of such a body. This is the simplest application of language, and this fact is immensely important. When we have difficulty with the grammar of our language we take certain primitive schemas and try to give them wider application than is possible. $^{5}$

Wittgenstein surely must have realized, but he appears to have been unable to come to terms with, the fact that everyday language has never been restricted to the kind of primitive languages he here invokes. Everyday language never was, and cannot be, devoid of metaphors.

Scholarship on Wittgenstein's philosophy of images does exist, but it does not amount to a continuous history; rather, it consists of a series of isolated attempts. When in 2000-2001 I had put together my first papers on the topic, ${ }^{6}$ the awareness I had of those attempts was far from complete. The studies I referred to were writings by Gombrich ${ }^{7}$, Wollheim $^{8}$, Kenny ${ }^{9}$, Genova $^{10}$, Mitchell $^{11}$, Roser ${ }^{12}$. Today I would add to that narrative of Wittgenstein research, from the early 1960s to the late 1990s, the names Aldrich ${ }^{13}$, Kjørup ${ }^{14}$, Blich ${ }^{15}$, Scholz $^{16}$, Biggs ${ }^{17}$, Boehm ${ }^{18}$, and, with qualifications, Lüdeking ${ }^{19}$. Let me here present the narrative in a nutshell.

Aldrich begins his 1958 paper by citing passages from Part I of the Philosophical Investigations where Wittgenstein uses the word 'picture' primarily in 
the sense of 'view', 'idea', and only by implication in a visual sense. But he also refers to $\$ 295$, noting that Wittgenstein makes 'the subtle point' that 'the picture as an image' can be evoked by an expression, ${ }^{20}$ and later in the paper $^{21}$ comes to Part II, sect. xi, mentioning the duck-rabbit drawing, and discussing the notions of 'noticing an aspect', 'picture-object', and 'seeing something as something'. However, Aldrich does not in the event provide even a rudimentary analysis of Wittgenstein's views on images, he does not explain what he means by his opening sentence 'Wittgenstein has a theory of pictorial meaning and picture-thinking', and it is not by chance that the paper in fact exerted more influence on the topic of Wittgenstein and metaphor ${ }^{22}$ than on the topic of Wittgenstein and images. ${ }^{23}$ By contrast, Ernst Gombrich's reference to the duck-rabbit 'trick drawing' and to its occurrence in the Philosophical Investigations, at the beginning of the introductory chapter of his seminal 1960 Art and Illusion ${ }^{24}$, could well have alerted scholarship to the fact that the later Wittgenstein had something important to say on the problem of pictorial meaning. But Gombrich, apparently, failed to have any impact on Wittgenstein scholarship, as did also, strangely, Richard Wollheim's 1968 Art and Its Objects, in which the author explicitly exploited and elaborated the Wittgensteinian notion of 'seeing as'.

Nor did any breakthrough come with Anthony Kenny's 1973 book Wittgenstein, in which the author, taking issue with the image of the 'two Wittgensteins', stressed that the early 'picture theory needs supplementing', rather than to be shown as false: the later 'theory of meaning as use is a complement rather than a rival to the picture theory'. ${ }^{25}$ However, Kenny's choice of the word 'complement' did not mean that he had as it were detected, and found worth considering, a theory of pictures in Wittgenstein's later philosophy. In fact, Kenny in that book had absolutely nothing to say about the later Wittgenstein's views on pictures or images. ${ }^{26}$ Almost another decade passed before there appeared the first study that actually had Wittgenstein's attempts at a theory of images as its subject: Søren Kjørup's 'Wittgenstein and the Philosophy of Pictorial Languages', a talk given in 1980. ${ }^{27}$ 'Pictures', wrote Kjørup,

always played an important role in the philosophical thought of Ludwig Wittgenstein. ... Wittgenstein never went so far as to formulate an explicit philosophy of pictures or philosophy of pictorial languages in its own right. ... But from his many asides on pictures and his many examples drawn from our use of and experience with pictures one does get a rather clear impression of his implicit 
conception of pictorial languages. ... And at certain points he even discusses pictures so straightforwardly and extensively that we come very close to an explicit theory. ${ }^{28}$

In his paper, Kjørup gives serious consideration to Wittgenstein's attempts, in Philosophical Investigations, Part II, sect. xi, to come to terms with the fact that pictures actually depict, that they represent by natural resemblance. Wittgenstein, as Kjørup puts it, does not deny in the Philosophical Investigations 'that there is a connection between pictorial objects and real ones'; on the contrary, he asserts that towards, say, a 'picture-face' one in some respects stands as one does towards a human face. 'I can study its expression, can react to it as to the expression of the human face. A child can talk to picture-men or picture-animals, can treat them as it treats dolls.' Wittgenstein, Kjørup points out, here writes about our very direct and live relation to pictures: "When I see the picture of a galloping horse-do I merely know that this is the kind of movement meant? Is it superstition to think I see the horse galloping in the picture?" Wittgenstein in fact 'stresses the difference between really experiencing a picture and just "reading" it, as we might say: "If you see the drawing as suchand-such an animal, what I expect from you will be pretty different from what I expect when you merely know what it is meant to be.", 29

However, after having given due scrutiny to these remarks by Wittgenstein, Kjørup deems them to be misguided. By contrast, he embraces the Wittgensteinian approach according to which as a 'point of departure for theorizing on pictures one should not take "idle" pictures, but pictures in use'. The philosopher of images whose approach is in accordance with what the later Wittgenstein actually was up to, stresses Kjørup, is Nelson Goodman; ${ }^{31}$ and what the later Wittgenstein was actually up to was the elaboration of a use-theory of pictures. These are ideas which today dominate the field. ${ }^{32}$

The first one to formulate an alternative set of ideas appears to have been Baruch Blich, in his 1987 Kirchberg talk "Natural Kinds" As a Kind of "Family Resemblance", ${ }^{33}$ Blich sets the tone of his argument by referring at quite some length to William Ivins' book Prints and Visual Communication ${ }^{34}$, in which the author points to the crucial role of pictorial representation in scientific argument and exposition, and to the verbal bias philosophy has suffered from for millennia, not possessing, and consequently not reflecting on, visual instruments. Blich underlines the fact that the later Wittgenstein, in the course of his philosophical expositions, not only exploits images, but that his 'use of 
pictorial representation is far more than an illustration, and it is well embedded in his philosophical approach'. ${ }^{35}$ As Blich sees the matter, Wittgenstein's notion of family resemblance can help us to understand the way in which a depicted object and the picture depicting it can resemble each other: 'Language games and family resemblance ... play ... an important role, because only with the help of such understanding of language are we able not only to create a given context for identifying vague elements of pictures, but by expanding the language game we stretch our reality to include new things. ... Unless we could extend our language and apply words to pictures, one would not be able to grasp their relevance for reality, and this is true of simple pictures as well as of sophisticated pictures such as caricatures, impressionist paintings, cubist paintings etc.' Here Blich adds a momentous observation, remarking that

[Wittgenstein's] idea of language games and their place in constituting new meanings, new concepts etc. in a given language, can account for new and unconventional generalizations. Practically it means that a prediction or a generalization ... can from now on be expressed even by metaphorical expressions, similes and the like, not to mention pictures as such. ${ }^{36}$

Blich's 1987 talk, crucially important though it was, remained without impact. ${ }^{37}$ Two years later Karlheinz Lüdeking gave a paper at Kirchberg ${ }^{38}$ in which he told about finding striking parallels between Wittgenstein on the one hand, and René Magritte, 'the one painter of classical modernity with a conspicuously Wittgensteinian attitude', on the other. ${ }^{39}$

Lüdeking discussed Magritte's 'Les mots et les images', reproducing and analyzing a fair number of the words-cum-images graphics from that little treatise (but no images from Wittgenstein's work), presenting Magritte as foreshadowing Goodman, and suggesting, practically, that the later Wittgenstein's views on pictorial meaning were quite similar to those of Goodman. Wittgenstein, writes Lüdeking, does already in his discussion of 'the picture of the two fencers' ${ }^{40}$ clearly distinguish 'what the picture shows from what it stands for. And what the picture stands for, he indicates, is not determined by its own structure but by our use of the picture. ... In a modified form we find the same thought in a much later remark about a picture of a different fighting sport in the footnote to paragraph 22 of the Philosophical lnvestigations. The picture shows a boxer, but what it represents, and even that it represents anything at 
all, can only be inferred from our use of it. ${ }^{91}$ Lüdekind has nothing to say on Wittgenstein's analyses of how pictures can have a direct, unmediated impact on us, as shown in particular in the Blue and Brown Books, ${ }^{42}$ or, for that matter, in sect. xi, Part II, of the Philosophical Investigations. Similarly, Oliver Scholz, who in his - on the whole extremely rewarding - 1991 book Bild, Darstellung, Zeichen ${ }^{43}$ although referring extensively to passages in the writings of the later Wittgenstein that can very well suggest a different conclusion, unequivocally attributes to him a use-theory of pictures.

Subsequent to Blich's 1987 talk, the possibility of a major breakthrough arrived, again, with Judith Genova's 1993 Kirchberg paper, 'Wittgenstein on Thinking: Words or Pictures?'44. As she there summed up the cognitive psychological background of her interpretation of Wittgenstein:

From an evolutionary perspective perhaps pictures represent an older form of thinking, one surpassed but never eliminated by words. ... Whatever the history, neither language nor thinking can do without their supplement of pictures. To the extent that we think in language, we think in pictures. ${ }^{45}$

And this is how she began her talk: 'contemporary epistemologists take words and pictures to be opposites. ... most would concur that thinking is discursive, not pictorial. ... Is thinking visual or verbal?-Wittgenstein's radical response is neither or either... In one sense, thinking is neither picturing nor speaking, but something else again. ... In another sense, however, thinking is either picturing or speaking. There is a family resemblance between the activities allowing for an exchange between them. ${ }^{46}$ Words, Genova said, necessarily engender pictures. As she put it: 'Pictures suffuse the speaking process. ... they make meaning possible by wedding the abstract word to a sensory embodiment. ${ }^{37}$

Just as with the earlier talk by Blich, Genova's 1993 paper, too, remained without echo. ${ }^{48}$ In the same year, the Bergen Wittgenstein Archives published the milestone compilation by Michael Biggs, 'A Source Catalogue of the Published Diagrams ${ }^{49}$, a work that for the first time called attention to the extent to which Wittgenstein made use of 'non-textual material'. ${ }^{50}$ The catalogue identified 479 'graphic elements' in the works of Wittgenstein printed to that date, with Biggs' 1995 paper 'Graphical Problems in Wittgenstein's Nachlaß' assessing the overall figure of published and unpublished graphic elements at 2500. By the mid-1990s a general awareness of the later Wittgenstein as 
a philosopher of not just the verbal but also of the visual, could well have emerged. But as a matter of fact it did not. An influential author, W. J. T. Mitchell, in his 1994 book Picture Theory, still spoke of 'Wittgenstein's iconophobia and the general anxiety of linguistic philosophy about visual representation' as being 'a sure sign that a pictorial turn is taking place', referring to 'the apparent paradox of a philosophical career that began with a "picture theory" of meaning and ended with the appearance of a kind of iconoclasm, a critique of imagery that led [Wittgenstein] to renounce his earlier pictorialism'. ${ }^{51}$ By contrast, Gottfried Boehm, in his seminal essay of the same year, 'Die Wiederkehr der Bilder' ${ }^{52}$, sees what he calls the 'iconic turn' as actually brought about by the work of the later Wittgenstein. It was Wittgenstein, Boehm stresses, who, by detecting the pictorial hidden in the verbal, ultimately led the way from the linguistic turn to an iconic turn. ${ }^{53}$ Boehm's crucial move is to spell out the fact that Wittgenstein's notion of family resemblances has an inevitably visual connotation: resemblances meet the eye, rather than speaking to abstract reason. ${ }^{54}$

Coming to the end of this preliminary narrative, let me refer to Andreas Roser's 1996 paper 'Are There Autonomous Pictures? Remarks on the Graphic Work of Otto Neurath and Ludwig Wittgenstein' ${ }^{55}$, a paper that was material to the awakening of my own interest in Wittgenstein's later philosophy of images. Wittgenstein's method of explaining philosophical points with the help of diagrams, Roser stresses, would have made no sense if he had really adhered to the position that images do not have an unequivocal meaning unless interpreted verbally. Roser's argument is that one could not speak of different applications of the same picture if one did not distinguish between the picture and its application. Of course, pictorial meaning is not independent of our use of pictures. But nor is it independent of the fundamental equivalences between the structure of the picture on the one hand, and the structure of what it depicts, on the other.

\section{Wittgenstein's Philosophy of Pictures}

What I had been attempting to show in my 2000-2001 papers on Wittgenstein's views on the role of images was, precisely, that those views included an awareness of pictures as natural carriers of meaning - the perspective Kjørup entertained way back in 1980 and then rejected. I referred, among many 
other passages in Wittgenstein's published writings, to one in the Blue Book where Wittgenstein calls attention to the possibility of 'a picture which we don't interpret in order to understand it, but which we understand without interpreting it'. There are, he writes, 'pictures of which we should say that we interpret them, that is, translate them into a different kind of picture, in order to understand them; and pictures of which we should say that we understand them immediately, without any further interpretation. ${ }^{56}$ I dwelled at length on some crucial passages in the Brown Book where Wittgenstein, touching on the issue of facial expressions, asks us to 'contemplate the expression of a face primitively drawn in this way ${ }^{57}$ :

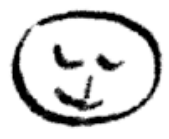

We should let this face, ${ }^{58}$ Wittgenstein continues, 'produce an impression' on us. We will then say: 'Surely I don't see mere dashes. I see a face with a particular expression.' And the point Wittgenstein makes here is that we cannot actually explain what this particular expression consists in. As he puts it: " "Words can't exactly describe it", one sometimes says. ... It is as though we could say: "This face has a particular expression: namely this" (pointing to something). But if I had to point to anything in this place it would have to be the drawing I am looking at.' One has an experience here, Wittgenstein implies, which cannot be conveyed by words; although it can be conveyed by pointing to a drawing. It appears our system of communication is incomplete, unless pictures play a part in it. ${ }^{59}$

Wittgenstein then goes on to describe two other cases where we would insist that we do not see 'mere strokes' or 'mere dashes'. First, when we say 'This is a face, and not mere strokes', distinguishing, for instance,

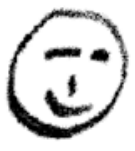

from

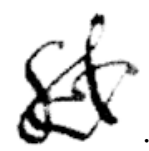

Secondly, the case of picture puzzles, when for instance "what at first sight appears as "mere dashes" later appears as a face. We say in such cases: "Now I see it as a face".' Wittgenstein stresses that this 'seeing it as a face' does not indicate any delusions; rather, it 'must be compared with seeing this drawing 


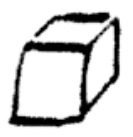

either as a cube or as a plane figure consisting of a square and two rhombuses. ${ }^{60}$ Some pages later, Wittgenstein experiments with the idea that instead of saying 'I see this as a face' we should really say 'I don't see this as a face, I see it like this'. We should refrain from circumscribing verbally what we can simply point to ${ }^{61}$ What ought to have entered our verbal framework here, Wittgenstein implies, is a non-verbal, pictorial, sign. This is the conclusion towards which the train of thought in the Brown Book in fact leads. And we are now in a position to see that what Wittgenstein in the so-called Part II of the Philosophical Investigations did was to take up, again, this train of thought. When studied together with the Brown Book, Part II of the Philosophical Investigations goes a long way towards giving a picture of what Wittgenstein's philosophy of pictures might amount to.

As to Part I of the Philosophical Investigations, among the passages I particularly referred to was $\S 450$, where Wittgenstein relates calling up the image of someone to mimicking the person's expression. Since to mimic is to evoke a resemblance, and since the ability to mimic is in critical respects more fundamental than the ability to speak, Wittgenstein here again implies that some kinds of visual representation can convey meaning without relying on verbal appendage. I also drew attention to the occurrence of the word 'picture' in the 1945 preface of the Investigations: he has produced an album, Wittgenstein there writes, made up of ever new pictures of the same sites. ${ }^{62}$ The word 'picture' is a metaphor here; but the metaphor - entirely absent in the 1938 version of the preface - is quite elaborate, the author likening himself to a poor draughtsman, with references made to picture cuts and to observers of landscapes. Significantly, in MS 130, where on p. 22 the term 'album' first makes its appearance, the passage in which it occurs is in fact immediately followed by an interesting sequence of pictures: drawings in connection with the seeing-as issue (see fig. 1 and 2 overleaf). This is one of the innumerable instances where a look at the Nachlass context adds additional meaning to what Wittgenstein says in the printed version. Wittgenstein's published writings clearly offer a wealth of important ideas on the social function of pictures, on pictorial meaning, and on pictorial communication. These ideas however, as I argued in my 2000-2001 papers, do not add up to a unified 


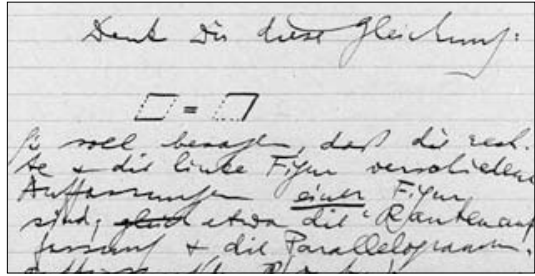

Fig. 1.

"verschiedene Auffassungen einer Figur"

(MS 130, p. 22)

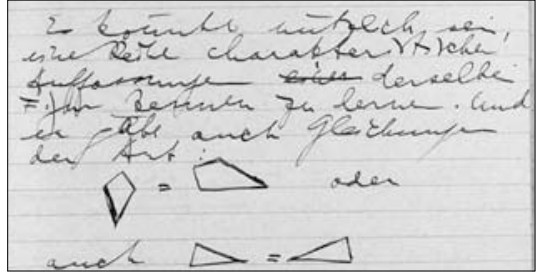

Fig. 2.

"eine Reihe charakteristischer Auffassungen derselben Figur" (MS 130, p. 23)

philosophy of pictures. In fact, the later Wittgenstein at no stage of his thinking possessed such a unified philosophy. He had significant insights, but no clear views as to what his problems actually were, or what he was striving to achieve. Hence he often abandoned ideas his interpreters today might find promising; and many ideas never made it to the printed editions of his writings. No attempt at constructing a coherent philosophy of pictures out of his insights can then, I suggested, succeed without taking account of the entire Nachlass; and I provided some examples of what working with the $\mathcal{N a c h}$ lass from this perspective might look like. One block of the Wittgensteinian corpus I should have covered, but did not, is the 1938 conversation notes edited by Cyril Barrett. ${ }^{63}$ I do not here have the space to make up for that omission. But let me single out two truly extraordinary passages.

First, the passage 'I remember walking in the street and saying: "I am now walking exactly like Russell." You might say it was a kinesthetic sensation. Very queer.-A person who imitates another's face doesn't do it before a mirror' ${ }^{64}$ Imitating, creating a resemblance, Wittgenstein implies, is primordially a motor affair. It definitely has nothing to do with rules or conventions.

The second passage: the admission that, at the end of the day, of course picturing hinges on likeness. However else could it do its job? Wittgenstein talks about how portraits resemble: 'If I give up the business of being like [as a criterion], I get into an awful mess, because anything may be his portrait, given a certain method of projection. ... If you're asked: "How do you know it is a thought of such and such?" the thought that immediately comes to your mind is one of a shadow, a picture. You don't think of a causal relation. The kind of relation you think of is best expressed by "picture", "shadow", etc.The word "picture", Wittgenstein here interjects, 'is even quite all right - in 
many cases it is even in the most ordinary sense, a picture. You might translate my very words into a picture.-But the point is this, suppose you drew this [picture], how do I know it is my brother in America? Who says it is himunless it is here ordinary similarity? ${ }^{36}$

\section{Metaphor: The Stumbling-Block for Wittgenstein's Later Philosophy}

A highly intriguing drawing by Wittgenstein is the one on p. 159 of MS 107, accompanying a remark jotted down on Nov. 10, 1929:

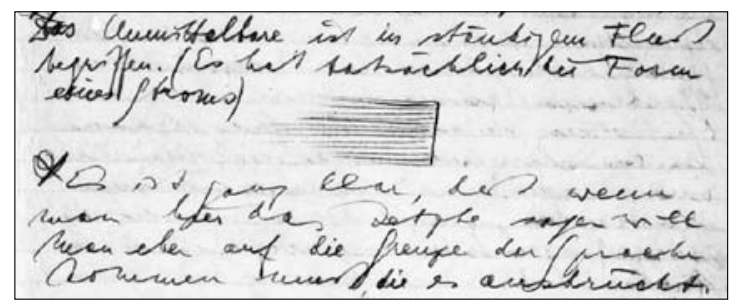

The immediate is in a constant flux [Fluß]. (It has in fact the form of a stream [Strom].) - It is quite clear that if one wants to say here the ultimate, one must thus come to the limit of the language which expresses it. ${ }^{66}$

It is remarkable that Wittgenstein found himself able to at least indicate in a drawing something he implied one cannot say. However, what he at this transitory stage in his philosophy regarded as a limit of language, he soon came to see simply as its lure. As Wittgenstein put it in 1932, just because a sentence 'sounds English', we take it to be 'sensible':

Thus, for example, we talk of the flow of time and consider it sensible to talk of its flow, after the analogy of rivers. ... Discussion of "the flow of time" shows how philosophical problems arise. Philosophical troubles are caused by not using language practically but by extending it ... We form sentences and then wonder what they can mean. ${ }^{67}$

Similarly in the Brown Book, where commenting on the question of the passage of time, Wittgenstein says: 
It is clear that this question most easily arises if we are preoccupied with cases in which there are things flowing by us, - as logs of wood float down a river. ... We then use this situation as a simile for all happening in time and even embody the simile in our language, as when we say "the present event passes by" (a log passes by), "the future event is to come" (a log is to come). We talk about the flow of events; but also about the flow of time - the river on which the logs travel. ${ }^{68}$

Extending language by using analogies and similes - the problem Wittgenstein here is encircling is that of metaphor. The metaphor of the flow of time, he suggests, is a philosophically dangerous one, which we should avoid by keeping close to everyday - 'practical'-language. However, Wittgenstein does not really seem to have made his case. He neither demonstrates that this metaphor invariably carries philosophical dangers, nor does he show that everyday language does not make spontaneous use of it. ${ }^{69}$ And I think this instance is symptomatic of Wittgenstein's difficulty. As I have indicated at the beginning of the present paper, the problem of metaphor, generally speaking, is one the later Wittgenstein has ultimately not been able to come to terms with.

The literature on Wittgenstein and metaphor is rich, but strangely discontinuous. From the point of view of my present paper, the most important study here is Marcus Hester's 1967 book, The Meaning of Poetic Metaphor: An Analysis in the Light of Wittgenstein's Claim that Meaning Is Use ${ }^{70}$. Hester provides an historical overview of metaphor theory, beginning of course with Aristotle, and including, among many others, I. A. Richards, René Wellek, Austin Warren, Max Black, and Rom Harré. He observes that Wittgenstein's 'remarks on metaphor are almost non-existent' ${ }^{\text {'1 }}$ (this is an observation subsequent scholarship will invariably and repeatedly make, but it is actually wrong, if the entire $\mathcal{N}$ achlass is taken into consideration); registers (and exaggerates, as mainstream Wittgenstein scholarship to this day does) Wittgenstein's 'attack on inner images" ${ }^{72}$, arguing however that on this point Wittgenstein is wrong: language, and not just poetic language, does indeed rely on visual mental images; ${ }^{.7}$ and elaborates the position that building on the one hand on Wittgenstein's theory of meaning as use, and, on the other hand, on the insight that language use actually involves evoking images, ${ }^{74}$ a theory of metaphor can be defended which vindicates the role of imagistic thinking, ${ }^{75}$ but would seem to be unacceptable to Wittgenstein. ${ }^{76}$ 
Hester's suggestions, at the time he made them in the mid-1960s, must have sounded entirely outlandish to the philosophical community. My impression is that his outstanding book remained largely without influence. There was one notable exception: Paul Ricoeur, in his 1975 study La métaphore vive ${ }^{77}$, did indeed discuss, and to some extent even assimilate, the connection Hester had established between image and metaphor. And Ricoeur's work, of course, has been widely read and cited. His references to Hester, however, went unnoticed. Jerry Gill, in his book Wittgenstein and Metaphor ${ }^{78}$, does acknowledge Ricoeur, but is unaware of Hester's book. He stresses that although, clearly, 'Wittgenstein had no explicit theory of metaphor', it 'is just as clear ... that his writings contain an implicit view of the nature and significance of metaphorical speech'. And the background of this implicit view is that the notion of language, as put forth in the Investigations, 'is congenial to the notion of metaphoric meaning by reason of its stress on the flexibility and functionality of linguistic phenomena. ... Wittgenstein's use of metaphor embodies a view of metaphor as both primordial and cognitive'. However, 'the literature on the role of metaphor in Wittgenstein's Philosophical Investigations is virtually non-existent'. ${ }^{79}$ The primary significance of Wittgenstein's work for philosophy, Gill believes, 'lies in his suggestion that at the most fundamental level philosophy is a metaphorical enterprise'. But Gill also maintains, and he appears to sense no tension here, that 'Wittgenstein relies most heavily upon the metaphoric mode, especially as it constitutes the heart of everyday speech, because it is at the practical level of existence that we are closest to the bedrock of our form of life'. ${ }^{80}$

While Gill was unaware of Hester, the authors of the 2004 volume Wittgenstein und die Metapher ${ }^{81}$ are aware neither of Hester nor of Gill. As the editors claim in their introduction to the volume: although the topic of metaphor has been widely discussed in the analytic tradition, and although the use of metaphorical language in the texts of some leading twentieth-century philosophers has received detailed scholarly attention, nothing similar has been attempted with regard to the philosophy of Wittgenstein. Also, the editors point out that while there are numerous places in Wittgenstein's later writings which indeed raise, for his philosophy, the question of how the border between literal and non-literal linguistic usage should be conceived of, still, 'one would search in vain for a theory of metaphor, or even the beginnings of such a theory, in his work'. ${ }^{22}$ One of the authors of the volume, Matthias Kroß, in his chapter 'The Self-Evidence of Metaphor: Wittgenstein's Relaxation of a Problem in the 
Philosophy of Language', again remarks that Wittgenstein practically never voiced an explicit opinion on the issue of metaphor, while his deliberations on language-games and on concepts bearing family resemblances to each other, have a clear implication: it does not make sense, anymore, to speak of the 'original', the 'literal' application of a concept. Some pages later, Kroß comes to describe Wittgenstein's diagnosis of the ultimate source of philosophy's ever unsolvable problems: these problems arise out of a misapplication of language, out of a carrying over of some specific linguistic usage from one sphere of discourse to another. ${ }^{83}$ But here, nearing the end of my paper, I am compelled to interject a question: why should that carrying over count as a misapplication? Kroß as it were highlights a contradiction in Wittgenstein's later philosophy; but he does not seem to realize the fact. Two authors of the same volume who do see this contradiction are Walter Mesch, discussing the unconvincing way Wittgenstein deals with the flow of time simile, ${ }^{84}$ and Rüdiger Zill ${ }^{85}$, referring to an early paper by Warren Shibles, in which the latter pointed out the discrepancies in Wittgenstein's attitude towards metaphor. $^{86}$

Shibles sides with the view that language is primarily metaphorical. For Wittgenstein however, as Shibles writes, 'whereas a language-game can change we must try to stick with the literal, original language-games we learned. ... Wittgenstein underplays the notion of metaphor and instead concentrates on getting language back into what he calls "ordinary" language. This underplay of metaphor however only accords with his explicit statement. In actual practice, as we can see by Wittgenstein's style of presentation and argument, he is a master at gaining insight by the use of analogy, metaphor and striking juxtapositions. ${ }^{87}$ Shibles here senses tension on two levels. At the surface level there is the tension between, on the one hand, Wittgenstein's not giving theoretical weight to metaphor, and on the other, his exuberant use of it. On a more fundamental level, there is a straightforward contradiction between Wittgenstein's claim of the primordial literalness of everyday language, and his stress on the multiplicity and flexibility of language-games. ${ }^{88}$ It is not at all the case that Wittgenstein was not occupied with the problem of metaphor. Especially MS 150 (1935-36), MS 152 (1936) and the later parts of MS 115 (1936) offer rich material on 'literal meaning' (eigentliche Bedeutung) and 'transposed meaning' (übertragene Bedeutung). In 1947, Wittgenstein jotted down a telling passage: 'But it is surely important that ... worry can be described in such words as: "the descent of a permanent cloud". I have perhaps never stressed 
the importance of this paraphrasing enough.- Think of happiness portrayed through a face surrounded by light, by rays emanating from it. ${ }^{99}$ Wittgenstein's problem was that he did not succeed in making his ideas on metaphor, and indeed his ideas on metaphor and images, converge with the main drift of TS 227 (the so-called 'Part I' of the so-called 'Philosophical Investigations'). It was this divergence, I believe, that prevented him from rounding out his later philosophy.

\section{Notes}

1 Ludwig Wittgenstein, Philosophical Investigations, translated by G. E. M. Anscombe, second edition (Oxford: Basil Blackwell, 1958).

2 Wittgenstein's Lasting Significance, edited by Max Kölbel and Bernhard Weiss (London: Routledge, 2004).

3 Anja Weiberg, "Ein Bild hielt uns gefangen": Die Kraft der Metapher', in Wittgenstein und die Metapher, edited by Ulrich Arnswald, Jens Kertscher and Matthias Kroß (Berlin: Parerga, 2004), 115-135.

4 Weiberg, "Ein Bild ...", 128.

5 'We might say', the passage continues, 'that it is the whole of philosophy to realize that there is no more difficulty about time than there is about this chair.' Wittgenstein's Lectures: Cambridge, 1932-1935, edited by Alice Ambrose (Oxford: Basil Blackwell, 1979), 119.

6 Kristóf Nyíri, 'The Picture Theory of Reason' (2000), in Rationality and Irrationality, edited by Berit Brogaard and Barry Smith (Wien: öbv-hpt, 2001), 242-266; Kristóf Nyíri, 'Pictures as Instruments in the Philosophy of Wittgenstein' (2001), in Wittgenstein and the Future of Philosophy: A Reassessment after 50 Years, edited by Rudolf Haller and Klaus Puhl (Wien: öbv\&hpt, 2002), 328-336; Kristóf Nyíri, 'Wittgenstein's Philosophy of Pictures' (2001), in Wittgenstein: The Philosopher and his Works, edited by Alois Pichler and Simo Säätelä (Working Papers from the Wittgenstein Archives at the University of Bergen, no. 17, 2005), 281-312 (reprinted: Frankfurt/M.: ontos verlag 2006, pp. 322-353).

7 Ernst H. Gombrich, Art and Illusion: A Study in the Psychology of Pictorial Representation (London: Phaidon Press, 1960).

8 Richard Wollheim, Art and Its Objects: An Introduction to Aesthetics (New York: Harper \& Row, 1968).

9 Anthony Kenny, Wittgenstein (Harmondsworth, Middlesex: Penguin Books, 1973). 
10 Judith Genova, 'Wittgenstein on Thinking: Words or Pictures?', in Philosophy and the Cognitive Sciences, edited by Roberto Casati and Graham White (Kirchberg am Wechsel: ÖLWG, 1993), 63-167. See also her Wittgenstein: A Way of Seeing (London: Routledge, 1995).

11 W. J. T. Mitchell, Picture Theory (Chicago: The University of Chicago Press, 1994).

12 Andreas Roser, 'Gibt es autonome Bilder? Bemerkungen zum grafischen Werk Otto Neuraths und Ludwig Wittgensteins', Grazer Philosophische Studien 52 (1996/97): 9-43.

13 Virgil C. Aldrich, 'Pictorial Meaning, Picture-Thinking, and Wittgenstein's Theory of Aspects', Mind 67 (1958): 70-79.

14 Søren Kjørup, 'Wittgenstein and the Philosophy of Pictorial Languages' (1980), in Wittgenstein - Aesthetics and Transcendental Philosophy, edited by Kjell S. Johannessen and Tore Nordenstam (Vienna: Hölder-Pichler-Tempsky, 1981), 159-173.

15 Baruch Blich, "Natural Kinds" As a Kind of "Family Resemblance", in Philosophy of Law, Politics and Society, edited by Ota Weinberger, Peter Kollee and Alfred Schramm (Proceedings of the 12th International Wittgenstein Symposium, 1987, Vienna: Hölder-Pichler-Tempsky, 1988), 284-289.

16 Oliver R. Scholz, Bild, Darstellung, Zeichen: Philosophische Theorien bildlicher Darstellung, revised second edition (Frankfurt/M.: Klostermann, 2004), first edition published in 1991.

17 Michael A. R. Biggs, 'A Source Catalogue of the Published Diagrams', in Wittgenstein: Two Source Catalogues and a Bibliography, edited by Michael Biggs and Alois Pichler (Working Papers from the Wittgenstein Archives at the University of Bergen, no. 7, 1993), 91-143; Michael A. R. Biggs, The Illustrated Wittgenstein: A Study of the Diagrams in Wittgenstein's Published Works (PhD thesis, University of Reading, UK, 1994); Michael A. R. Biggs, 'Graphical Problems in Wittgenstein's Nachlaß', in Culture and Value: Philosophy and the Cultural Sciences, edited by Kjell S. Johannessen and Tore Nordenstam (Kirchberg am Wechsel: ÖLWG, 1995), 751-761.

18 Gottfried Boehm, 'Die Wiederkehr der Bilder', in Was ist ein Bild?, edited by Gottfried Boehm (München: Wilhelm Fink Verlag,1994), 11-38.

19 Karlheinz Lüdeking, 'Picture-Theory of Language and Language-Theory of Pictures', in Wittgenstein - A Re-evaluation, edited by Rudolf Haller and Johannes Brandl (Proceedings of the 14th International Wittgenstein Symposium, 1989, vol. III, Vienna: Hölder-Pichler-Tempsky, 1990), 312-316.

20 Aldrich, 'Pictorial Meaning', 71. 
21 Aldrich, 'Pictorial Meaning', $73 \mathrm{f}$.

22 As evidenced by Marcus B. Hester, The Meaning of Poetic Metaphor: An Analysis in the Light of Wittgenstein's Claim that Meaning Is Use (The Hague: Mouton, 1967) and Rüdiger Zill, 'Der Vertrakt des Zeichners: Wittgensteins Denken im Kontext der Metapherntheorie', in Wittgenstein und die Metapher (cf. note 3 above). Although the term 'metaphor' does not actually occur in Aldrich's paper, it appropriately came to be reprinted in the volume Essays on Metaphor, edited by Warren A. Shibles (Whitewater, WI: Language Press, 1972), 93-103.

23 But see the brief reference to Aldrich in Emmanuel Alloa, 'Seeing-As, Seeing-In, Seeing-With: Looking through Images', in Image and Imaging in Philosophy, Science and the Arts, volume 1, Proceedings of the 33rd International Ludwig Wittgenstein Symposium, edited by Richard Heinrich, Elisabeth Nemeth, Wolfram Pichler and David Wagner (Frankfurt: ontos Verlag, 2011), 168.

24 Cf. note 7, above.

25 Kenny, Wittgenstein, 226.

26 In the same year that his book on Wittgenstein was published, Kenny had finished his translation of the so-called Philosophical Grammar, a mis-edition by Rush Rhees, as we today know, of Wittgenstein's TS 213 (the 'Big Typescript'). One might hypothesize that Kenny here was overly impressed with Wittgenstein's formula, 'Anything can be a picture of anything, if we extend the concept of picture sufficiently.' (Ludwig Wittgenstein, Philosophical Grammar, translated by Anthony Kenny [Berkeley: University of California Press, 1974], 163.) Wittgenstein himself did not adhere to this formula for much longer; 1936 is the year it surfaces for the last time in his manuscripts. Kenny however is still in a way influenced by it as late as in 1993, in his book on Aquinas. As he there puts it: 'there is good reason to believe that what makes an image of $\mathrm{X}$ an image of $\mathrm{X}$ is never its resemblance to X' (Anthony Kenny, Aquinas on Mind [London: Routledge, 1993], 99).

27 Cf. note 14 above.

28 Kjørup, 'Wittgenstein ...', 159.

29 Kjørup, 'Wittgenstein ...', 168.

30 Kjørup, 'Wittgenstein ...', 171.

31 Kjørup, 'Wittgenstein ...', 167 f. and 172.

32 Kjørup actually exerted a real influence here. Scholz, the leading German proponent of attributing a use-theory of pictures to Wittgenstein, refers in his Bild, Darstellung, Zeichen (cf. note 16 above), both to Kjørup's 'George Inness and the Battle at Hastings, or Doing Things With Pictures', The Monist 58 (April 1974): 
216-235, and to his 'Pictorial Speech Acts', Erkenntnis 12 (1978): 55-71, though without mentioning his 'Wittgenstein and the Philosophy of Pictorial Languages'.

33 Cf. note 15 above.

34 William M. Ivins, Jr., Prints and Visual Communication (Cambridge, MA: Harvard University Press, 1953).

35 Blich, 'Natural Kinds', 285.

36 Blich, 'Natural Kinds', 288.

37 The only reference to the talk I am aware of is one by Dieter Mersch, in his 'Wittgensteins Bilddenken', Deutsche Zeitschrift für Philosophie 54 (December 2006), 939 , note 2 .

38 Cf. note 19 above.

39 Lüdeking, 'Picture-Theory ...', 312.

40 Lüdeking here refers to Wittgenstein's notebook entry of 29. 9. 1914.

41 Lüdeking, 'Picture-Theory ...', 316.

42 Ludwig Wittgenstein, Preliminary Studies for the 'Philosophical Investigations': Generally Known as the Blue and Brown Books, edited by Rush Rhees (1958; reprint, Oxford: Basil Blackwell, 1964), see esp. 36 f., 105, 125, 162-174.

43 Cf. note 16 above.

44 Cf. note 10 above.

45 Genova, 'Wittgenstein on Thinking', 166.

46 Genova, 'Wittgenstein on Thinking', 163.

47 Genova, 'Wittgenstein on Thinking', 164.

48 Nor did her 1995 book Wittgenstein: A Way of Seeing receive much attention. I was relieved to register that, at the 2010 Kirchberg Wittgenstein Symposium, Marianne Richter repeatedly referred to Genova's book in her talk 'Methodologische Aspekte des Bildgebrauchs bei Wittgenstein', in Image and Imaging in Philosophy, Science and the Arts, Papers of the 33rd Wittgenstein Symposium, edited by Richard Heinrich, Elisabeth Nemeth, and Wolfram Pichler (33rd International Wittgenstein Symposium, Kirchberg am Wechsel: ALWS, 2010), 271-273.

49 Cf. note 17 above.

50 Biggs' doctoral dissertation The Illustrated Wittgenstein, a work replete with novel ideas and significant bibliographical references, remains sadly unknown to the scholarly community.

51 W. J. T. Mitchell, Picture Theory (Chicago: The University of Chicago Press, 1994), $12 \mathrm{f}$.

52 Cf. note 18 above.

53 'Wittgensteins Theorie bedeutet in der Geschichte der "ikonischen Wendung" 
einen vorläufigen Endpunkt und insofern einen Durchbruch, als es die Befragung der Sprache war, welche der ihr innewohnenden Bildpotenz Nachdruck verschaffte, den linguistic turn in einen iconic turn überleitete' (Boehm, 'Die Wiederkehr der Bilder', 14).

54 'Ähnlichkeiten stimulieren eine vergleichende Wahrnehmung, sie appellieren stärker ans Auge, als an den abstrakten Verstand' (Boehm, 'Die Wiederkehr der Bilder', 14).

55 Cf. note 12 above.

56 Wittgenstein, The Blue Book, 36.

57 Wittgenstein, The Brown Book, 162.

58 The drawing is taken from the Bergen Electronic Edition, item 310, page 132. The same edition is the source of all subsequent graphics in the present paper.

59 This implication will be somewhat later explicitly spelled out by Wittgenstein, cf. The Brown Book, 174.

60 Wittgenstein, The Brown Book, 163.

61 Wittgenstein, The Brown Book, 170.

62 Wittgenstein, Philosophical Investigations, vii, third paragraph. The word 'Bild' occurs twice in this paragraph, but in the English translation only the second occurrence is translated as 'picture'. The first occurrence, 'immer neue Bilder ent- worfen', is rendered as 'new sketches made'.

63 Ludwig Wittgenstein, Lectures and Conversations on Aesthetics, Psychology and Religious Belief, edited by Cyril Barrett (Berkeley: University of California Press, 1967). It was the title of the talk by Martin Kusch, 'The Concept of Picture in Wittgenstein's "Lectures on Religious Belief", as announced in the preliminary program of the 2010 Kirchberg symposium, that alerted me to the relevance of this volume to a fuller understanding of Wittgenstein's philosophy of images.

64 Wittgenstein, Lectures on Religious Belief, 39. In Wittgenstein's manuscripts, two years later there occurs the formulation (MS 123, pp. $20 \mathrm{r} / \mathrm{v}$ ): 'Wissen wie jemand geht: es sich vorstellen können - aber auch: es nachmachen können. Muß man sichs vorstellen, um es nachzumachen? Und ist es nachmachen nicht ebenso stark, als es sich vorstellen?' By 1944 this becomes (MS 129, pp. $181 \mathrm{f}$, cf. the reference to PI $\S 450$ above): 'Wissen, wie jemand geht /ausschaut/: es sich vorstellen können - aber auch: es nachmachen /ahmen/ können. Muß man sich's vorstellen, um es nachzumachen? Und ist es nachmachen /ahmen/ nicht ebenso stark, als es sich vorstellen?'

65 Wittgenstein, Lectures on Religious Belief, $66 \mathrm{f}$.

66 With a single word changed, I am quoting this passage in the translation given by 
David Stern, in his pathbreaking 'Heraclitus' and Wittgenstein's River Images', The Monist 74 (Oct. 1991), 588.

67 Wittgenstein's Lectures (cf. note 5 above), 13 and 15.

68 Wittgenstein, The Brown Book, $107 \mathrm{f}$. And a highly interesting Nachlass passage, written roughly at the same time: 'wenn uns beim Nachdenken über die Zeit das Bild des Vorüberfließens gefangen hält ... Wie etwa, wenn wir an einem Fluß stehen auf dem Holz geflößt wird: die Stämme ziehen an uns vorüber; die, welche vorüber sind, sind alle rechts von uns, die noch kommen, sind links. ... Wir sprechen vom Lauf der Ereignisse, aber auch vom Laufe der Zeit, - des Flusses, auf dem die Stämme vorbeischwimmen. ("die Zeit ist da", "die Zeit ist längst vorbei", "es kommt die Zeit", etc., etc.) Und so kann mit dem Wort "Zeit" das Bild eines ätherischen Flusses untrennbar verbunden sein, mit den Worten "Vergangenheit" \& "Zukunft" das Bild von Gebieten, Ländern, aus deren einem die Ereignisse in das andre ziehen. Und doch können wir natürlich keinen solchen Strom finden \& keine solchen Örter. Die Grammatik unserer Sprache läßt eben Fragen zu, zu denen es keine Antwort gibt. Und sie verleitet uns zu ihnen durch die Bildhaftigkeit des Ausdrucks. Eine Analogie hat unser Denken gefangen genommen \& schleppt es unwiderstehlich mit sich fort' (MS 115, p. 172).

69 This is brilliantly argued by Walter Mesch. As he writes: 'die Rede vom Vergehen, Verrinnen oder Verfliegen der Zeit [findet] bereits in der gewöhnlichen Sprache in vielen Varianten Verwendung... Dies dürfte kaum zu verstehen sein, wenn darin nicht irgendwelchen Erfahrungen Ausdruck verliehen wäre, die man im gewöhnlichen Leben machen kann. ... Bei der Rede vom Fluss der Erscheinung oder Zeit scheint es sich nicht um eine falsche Verwendung der Sprache handeln zu können, die erst dann auftritt, wenn wir philosophieren. Wenn hier etwas zu kritisieren ist, scheint die Kritik auch auf den gewöhnlichen Sprachgebrauch bezogen werden zu müssen; und dies kann für jemanden, der seine Hauptaufgabe darin sieht, gegen die vermeintlichen Selbstverständlichkeiten des philosophischen Sprachgebrauchs auf den gewöhnlichen Sprachgebrauch zu verweisen, keineswegs unproblematisch sein. Es sieht so aus, als drohten sich Wittgensteins Einsichten gegen ihn selbst zu wenden.' Mesch, 'Die Metaphern vom Vergehen und vom Fluss der Zeit: Überlegungen im Anschluss an eine Bemerkung Wittgensteins', in Wittgenstein und die Metapher (cf. note 3 above), 273 and 277.

70 Cf. note 22 above.

71 The Meaning of Poetic Metaphor, 31.

72 The Meaning of Poetic Metaphor, $37 \mathrm{ff}$., cf. also 34.

73 The Meaning of Poetic Metaphor, 69, 92, 96, and esp. $133 \mathrm{ff}$. 
74 The Meaning of Poetic Metaphor, 98 f., 113.

75 The Meaning of Poetic Metaphor, 39, $111,176 \mathrm{f}$.

76 The Meaning of Poetic Metaphor, 23 f., 96, 108, 113, 191.

77 English translation: The Rule of Metaphor: The Creation of Meaning in Language (London: Routledge, 2003). Well before the English translation, a German one was published: Die lebendige Metapher (München: Wilhelm Fink, 1986).

78 Jerry H. Gill, Wittgenstein and Metaphor (1981; new and revised edition, New Jersey, Humanities Press, 1996). A first draft was Jerry H. Gill, 'Wittgenstein and Metaphor', Philosophy and Phenomenological Research 40 (1979): 272-284.

79 Gill, Wittgenstein and Metaphor, 82.

80 Gill, Wittgenstein and Metaphor, 99, 108 f., 128 and 130.

81 Cf. note 3 above.

82 'Eine Theorie der Metapher oder Ansätze dazu wird man in Wittgensteins Werk ... vergeblich suchen' (Wittgenstein und die Metapher, $11 \mathrm{f}$.).

83 Kroß, 'Die Selbstverständlichkeit der Metapher: Wittgensteins Entspannung eines sprachphilosophischen Problems', in Wittgenstein und die Metapher, 31 f. und 34.

84 Cf. note 69 above.

85 Cf. note 22 above.

86 For Zill's reference to Shibles, see Wittgenstein und die Metapher, $162 \mathrm{f}$.

87 Warren A. Shibles, Wittgenstein, Language and Philosophy (Dubuque, IA: Kendall/ Hunt, 1969), $2 \mathrm{f}$.

88 This is the 'incompatibility', I believe, Schulte ultimately hints at in his 'Wittgenstein's Notion of Secondary Meaning and Davidson's Account of Metaphor-a Comparison', Grazer Philosophische Studien 36 (1989), 145.

89 'Es ist aber doch wichtig, daß ... man die Sorge mit den Worten beschreiben kann "Ewiges Düstre steigt herunter". Ich habe vielleicht die Wichtigkeit dieses Paraphrasierens nie genügend betont. - Man stelle die Freude dar durch ein lichtumflossenes Gesicht, durch Strahlen, die von ihm ausgehen.' (MS 134, p. 52. The first part of this passage has been published as $\S 517$ of Zettel, translated by G. E. M. Anscombe, second edition [Oxford: Basil Blackwell, 1981]. Miss Anscombe renders 'Sorge' as 'care'.) 
